but they also point out some of the limitations of the method Prof. Schapera has followed in the present volume. Since the conclusions that emerge from his comparison are couched in terms of a theory of 'development', it would seem that the units of comparison do not in fact belong to the same order of social organization. Prof. Schapera indicates the areas of social life into which one must inquire in studying political organization. It is to be hoped that he will follow this up with a comparative study of the Southern Bantu alone, to whom the bulk of the material presented is in fact devoted, where one is dealing with units of the same order of social organization.

A. L. Epstein

\section{TRAVELS IN SOUTH AMERICA}

Highway of the Sun

By Victor W. von Hagen. Pp. $264+21$ plates. (London: Victor Gollancz, Ltd., 1956.) 18s. net.

Tupari

By Dr. Franz Caspar. (Translated by Eric Northcott.) Pp. viii $+224+16$ plates. (London : G. Bell and Sons, Ltd., 1956.) 18s. 6d. net.

THESE two books have one characteristic in common, namely, that both are popular aecounts of their author's' travels in South America, but that they do not set out to describe any scientific discoveries their expeditions may have made.

Mr. von Hagen's object was to follow and record the Inca roads in Peru. The general lines of the road system were already known, but the expedition has doubtless filled in details, verified the physical remains of the roads and plotted them on maps. They trested the pace of local relay runners at an altitude of about 14,000 ft., finding that it would have been possible, as the chroniclers said, to cover the distance from Cuzco to Quito in twenty-four hours, and this is perhaps the most interesting piece of information in the book. For part of the journey on the coast there were archæologists in the party, but their chief concern was not with the roads and their results are for publication elsewhere. Had they been consulted they could have saved the author from publishing a picture of a tapestry of much later date as a mummy wrapping from Paracas Cavernas (p. 192), and a double whistling jar of Coast Inca type as Mochica, which is much older (p. 224).

No one will claim that travel off the beaten track in Peru is comfortable, and the discomforts and dangers of the journey lose nothing in the telling. The expedition had one eye on the New York Times, to which it sent frequent cables, and the style in which the book is written is sufficiently indicated by the sub-title, which describes the roads as "fabulous high-roads".

Dr. Caspar, who was returning from Bolivia to Europe, wished to visit and study some forest Indians who had not been changed by acculturation. $\mathrm{He}$ succeoded in joining a small group of about two hundred people in the Brazilian forests, who called themselves Tupari, although they turned out to be an agglomeration of the remnants of various tribes. $\mathrm{He}$ lived among them for about six months, gained their confidence, worked and hunted with them, and took part in some of their ceremonies; in fact, he seems to have done almost everything except respond to the advances of the wife they offered to him. The story is told in a straightforward and interesting manner, and it gives a good general idea of the way the Indians lived. It mentions some of the clues which the author obtained about their beliefs. The book does not give any details about how they built their houses or made their pots, the material of their arrowheads, the form of their stone tools or the exact nature of their musical instruments. There is no map, apart from a sketch map of a small area which serves no useful purpose, and there is no index. The author made extensive ethnological collections and could doubtless publish details about them elsewhere, but so far as I am aware he has done little in this way.

There is a sad postscript describing briefly a subsequent visit six years later, in 1955. Two-thirds of the group had died of measles, caught from rubber gatherers. The remainder had adopted European dress, and fallen, as the author says, victims to eivilization.

G. H. S. Bushneli

\section{TRANSMISSION-LINE THEORY}

Transmission-Line Theory

By Prof. Ronald W. P. King. Pp. xii +509. (London : MeGraw-Hill Publishing Company, Ltd., 1955.) $90 s$.

7 HIS book gives what is probably the most

comprehensive treatment of the radio-frequency transmission line which has been published. The basic theoretical treatment is applicable to all frequencies, of course, but effects which are negligible except at high radio-frequencies are dealt with at length.

The first chapter deals with the infinitely long line by both the distributed-circuit and the electromagnetic-field methods and discusses thoroughly the limitations of the former. Parallel-wire lines (two, three or four wires, screened or unscreened), coaxial lines and strip lines are all discussed.

The terminated line is then treated, including the conducting pistons and disks used as terminations at very high frequencies. A consideration of the impedance and admittance of lines follows, including stub and other methods of modifying impedances, balanced to unbalanced transformations and hybrid junctions. Matrix methods of solution are used here. It seems a pity that anyone, having thought out an elegant arrangement for dealing with balanced to unbalanced lines (p. 207), should call it an 'unbalance squelcher', but for this Prof. King cannot be held responsible.

The distribution of current and voltage along a line, the measurement of standing-wave ratio and $Q$-factor from the current distribution, are topics which are thoroughly discussed. Many different forms of discontinuity are treated.

This book would overwhelm any reader who was just commencing the study of lines, because the author insists on a rigorous treatment, without introducing approximations until a late stage in the discussion. It should, however, prove a useful and stimulating book for any reader who has already a fairly good knowledge of the subject, and it will also be very useful to the radio engineer who needs the theoretical treatment of some specific line problem such as, for example, the effect of a bend in a parallelwire line.

The book is well produced, the mathematics being well set out and the numerous graphs and diagrams adequate in size. Rationalized M.K.S. units are used.
C. R. STONer 